\title{
MENCAPAI KEUNGGULAN BERSAING DENGAN STRATEGI DIFERENSIASI
}

\author{
Dwi Sulistiani \\ Jurusan Akuntansi Fakultas Ekonomi \\ Universitas Islam Negeri Maulana Malik Ibrahim Malang \\ Jl. Gajayana No. 50, Tlp 0341-558881, Fax. 0341-558881 \\ e-mail: tiaraakbar2006@yahoo.com
}

\begin{abstract}
A strategy is needed because of the competition and the right strategy is to win the competition. Porter (1980) argued that the formulation of competitive strategy is to connect the company with its environment. Although the relevant environment is very broad, encompassing social forces as well as economic forces, the main aspects of the environment are industrial companies or industries in which the company competes. There needs to be a strategy known as generic strategy is the fundamental way for the company to achieve profitability above the industry average by having a sustainable competitive advantage. The strategy consists of : cost leadership strategy (cost leadership), differentiation strategy (differentiation), and a strategic focus (focus either cost leadership or differentiation focus). This article focuses on diferensisi strategy for achieving competitive advantage of a company.

Some previous article that discussed the effect of differentiation strategy on competitive advantage, stating that the differentiation strategy to significantly affect a company's competitive advantage. Understanding the importance of differentiation strategies companies can make a difference with its competitors, so as to compete in a more competitive market, and could win the competition. This research can help companies that already distinguishes itself with competitors, may further reinforce and communicate the difference.
\end{abstract}

Keywords: generic strategy, differentiation strategy, competitive advantage

\section{Abstraksi}

Suatu strategi dibutuhkan karena adanya persaingan dan strategi yang tepat adalah bagaimana memenangkan persaingan. Porter (1980) menyatakan bahwa perumusan strategi bersaing adalah menghubungkan perusahaan dengan lingkungannya. Walaupun lingkungan yang relevan sangat luas, meliputi kekuatan-kekuatan sosial sebagaimana juga kekuatankekuatan ekonomi, aspek utama dari lingkungan perusahaan adalah industri atau industriindustri dalam mana perusahaan tersebut bersaing. Perlu adanya strategi yang dikenal dengan strategi generik yang merupakan cara mendasar bagi perusahaan untuk mencapai profitabilitas diatas rata-rata industri dengan memiliki sustainable competitive advantage. Strategi tersebut terdiri dari : strategi kepemimpinan biaya (cost leadership), strategi diferensiasi (differentiation), dan strategi focus (baik focus kepemimpinan biaya ataupun focus diferensiasi). Artikel ini lebih memfokuskan pada strategi diferensisi untuk mencapai keunggulan bersaing suatu perusahaan.

Beberapa artikel sebelumnya yang membahas mengenai pengaruh strategi diferensiasi terhadap keunggulan bersaing, menyatakan bahwa strategi diferensiasi secara signifikan 
mempengaruhi keunggulan bersaing suatu perusahaan. Memahami pentingnya strategi diferensiasi perusahaan dapat menciptakan perbedaan dengan pesaingnya, sehingga mampu bersaing di pasar yang lebih kompetitif, dan bisa memenangkan persaingan. Penelitian ini bisa membantu perusahaan yang sudah membedakan dirinya dengan pesaing, dapat lebih mempertegas dan mengkomunikasikan perbedaannya.

Kata kunci : strategi generik, strategi diferensiasi, keunggulan bersaing

\section{PENDAHULUAN}

Dalam sebuah strategi kemenangan adalah segalanya. Namun perlu didasarkan pada suatu pemikiran bahwa suatu strategi perlu terdapat konsep, kerangka kerja, dan teknik yang dapat digunakan untuk menyusun dan menjalankan strategi secara efektif. Dengan demikian maka tujuan dari pada strategi adalah membantu kita untuk menang. Kesuksesan pada suatu organisasi dihasilkan dari strategi yang diformulasikan dengan baik dan dijalankan secara efektif.

Menurut Grant (1997: 25), meskipun strategi dapat membantu pencapaian suatu keberhasilan, strategi tidak menjamin keberhasilan. Ada beberapa faktor yang menunjang tercapainya suatu sukses sebagai berikut :

1. Tujuan yang sederhana, konsisten dan berjangka panjang.

2. Pemahaman yang baik mengenai lingkungan persaingan

3. Penilaian yang baik mengenai sumber daya yang dimiliki

4. Pelaksanaan yang efektif.

Sinergi dari ke empat hal tersebut diatas diharapkan dapat membawa keberhasilan suatu organisasi yang akan diraihnya sesuai dengan tujuan yang telah ditetapkan serta dapat menyikapi lingkungan persaingan dengan arif dan bijaksana dan mengeksploitasi sumberdaya yang dimiliki oleh organisasi dengan melindungi kelemahan-kelemahan yang ada di dalam organisasi.

Suatu strategi dibutuhkan karena adanya persaingan dan strategi yang tepat adalah bagaimana memenangkan persaingan. Porter (1980) menyatakan bahwa perumusan strategi bersaing adalah menghubungkan perusahaan dengan lingkungannya. Struktur industri mempunyai pengaruh yang kuat dalam menentukan aturan permainan persaingan selain strategi-strategi yang secara potensial tersedia bagi perusahaan. Kekuatan-kekuatan di luar industri penting terutama dalam artian relatif; karena kekuatan-kekuatan luar biasanya mempengaruhi semua perusahaan yang ada dalam suatu industri, maka kuncinya terletak 
pada kemampuan yang berlainan di antara perusahaan-perusahaan yang bersangkutan untuk menanggulanginya.

Sedangkan menurut Hitt, Ireland \& Hoskisson (1997) mengatakan bahwa Strategi keunggulan biaya (cost leadership strategy) menyediakan barang atau jasa dengan karakteristik yang dapat diterima pelanggan pada harga bersaing yang serendah mungkin. Sebaliknya strategi diferensiasi (differentiation strategy) menyediakan produk yang diyakini konsumen sebagi suatu yang unik dalam hal yang penting bagi mereka. Sedangkan strategi fokus (focus strategy) dilaksanakan ketika perusahaan mencoba untuk menggunakan kompetensi intinya untuk menyediakan kebutuhan suatu kelompok pembeli tertentu dalam suatu industri.

Strategi diferensiasi adalah produk yang ditawarkannya berbeda dari satu atau lebih para pesaing, melalui suatu cara atau banyak cara yang dapat dinilai oleh para pelanggan sehingga mempengaruhi pilihan pelanggan. Strategi diferensiasi sering, tetapi tidak selalu, dihubungkan dengan harga yang lebih tinggi, karena besarnya kenaikan membuat harga kurang tepat pada konsumen. Selain berdasarkan pada keungulan biaya rendah, keberhasilan strategi akan dibedakan dalam banyak cara, di antaranya dengan cara menaikkan penampilannya, kualitas, prestise, ciri utama, jaminan pelayanan, reliabilitas atau keyakinan pada produk.

Dalam mengembangkan maksud diferensiasi perlu adanya pedoman dari sudut pandang pelanggan. Bagaimana penggunaan produk oleh pelanggan, harus dicermati secara mendalam untuk mengerti komponen-komponen apa yang memenuhi harapan. Secara keseluruhan tujuan diferensiasi meningkatkan pembelian, kepuasan atau loyalitas pelanggan. Oleh karena itu analisa pelanggan dan pesaing harus dapat memberikan makna perbedaan guna meningkatkan nilai manfaat yang sesuai. Akhirnya maksud diferensiasi yang diusulkan harus diperiksa dengan menentukan reaksi para pelanggan dan barangkali dengan melakukan analisa ekonomi dan sudut pandang pelanggan.

Maksud diferensiasi adalah memudahkan penyediaan nilai yang cukup kuat pada barang bagi pelanggan dan diharapkan para pelanggan menyadari bahwa nilai itu ada, yang selanjutnya manfaat akhirnya harus dapat mempengaruhi keputusan pelanggan. Jika maksud diferensiasi ini dapat terlihat dengan mudah dikenali dalam ukuran atau secara mudah dicocokkan atau dihitung oleh pelanggan, maka suatu strategi keunggulan bersaing yang efektif akan terjadi.

Dalam melakukan penulisan ini, tujuan yang ingin dicapai adalah : 
1. Untuk mengetahui apa itu strategi generik, strategi diferensiasi dan keunggulan bersaing

2. Untuk membahas bagaimana keunggulan bersaing bisa dicapai dengan strategi diferensiasi.

Tulisan ini diawali dengan konsep strategi, srategi generik menurut Porter (1980), strategi diferensiasi, sumber-sumber diferensiasi, keunggulan bersaing, penelitian terdahulu yang terkait dengan tema dan diakhiri dengan simpulan dan saran

\section{PEMBAHASAN}

\section{Pengertian Strategi}

Pearce \& Robinson (1997 : 8) mendefinisikan manajemen strategi sebagai berikut :

"Strategic management is defined as the set of decisions and actions that result in the formulation and implementation of plans designed to achieve a company's objectives".

Sedangkan Hunger \& Wheelan (1995 : 3) mendefinisikan strategic management sebagai berikut :

"Strategic Management is that set of managerial decisions and actions that determines the long run performance of a corporations".

Definisi tersebut diatas mengandung arti bahwa manajemen strategi sebagai sekumpulan tindakan komprehensif dan terpadu yang menghasilkan perumusan dan pelaksanaan rencana yang dirancang untuk mencapai sasaran perusahaan. Strategi adalah suatu sarana bagi organisasi untuk mencapai tujuannya, karena merupakan sarana maka strategi diharapkan dapat menjawab tantangan dan merebut peluang yang ada melalui persaingan yang semakin kompetitif di masa yang akan datang dengan berbagai keunggulan yang dimiliki suatu organisasi.

\section{Strategi Generik Menurut Porter}

Berikut ini adalah definisi strategi kompetitif menurut Porter (1980: 25)

"Competitive Strategy is about being different. It means deliberately choosing to perform activities differently or to perform different activities than rivals to deliver a unique mix of value”.

Gambaran strategi generic menurut Poter (1980: 26) digambarkan sebagai berikut :

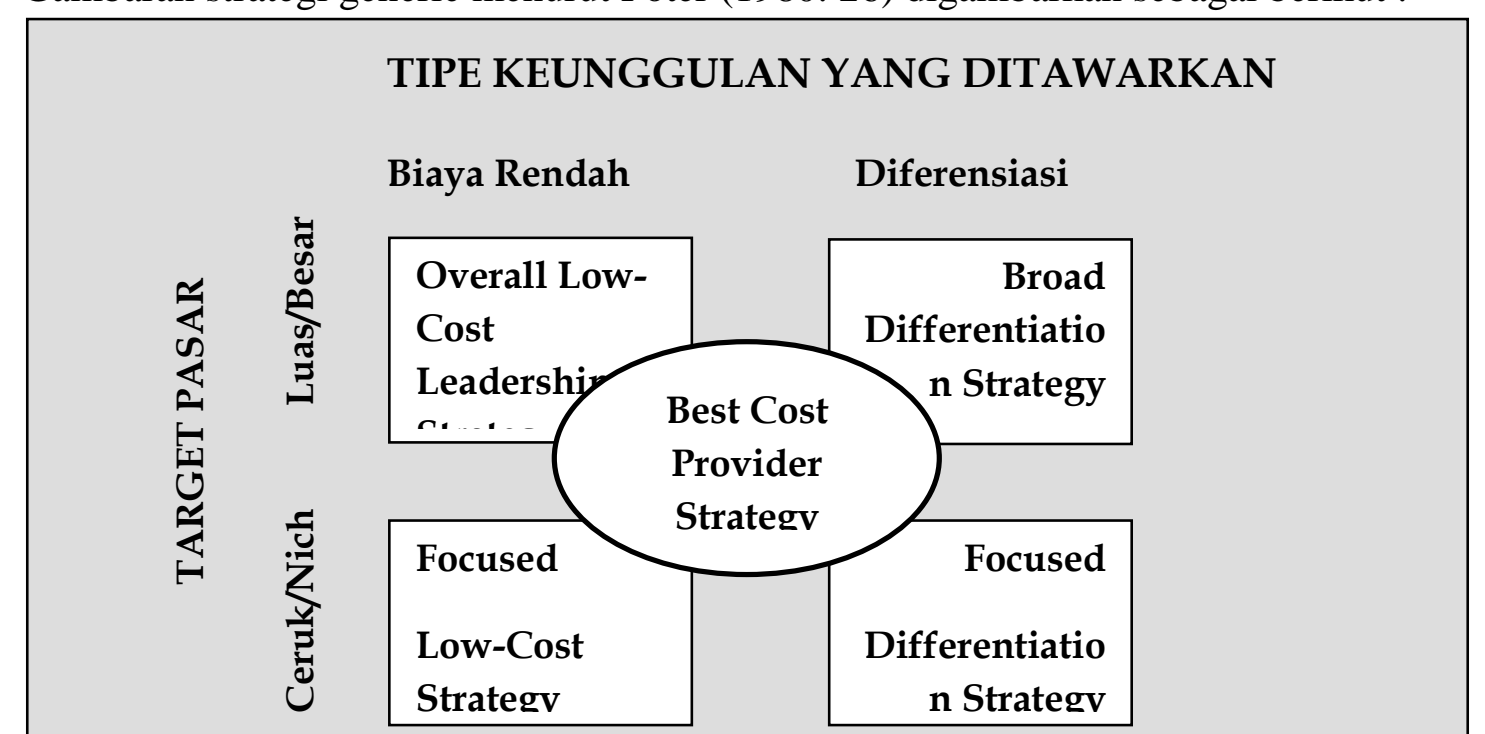




\section{Low-Cost Leadership Strategy}

- Bisnis dijalan dengan biaya rendah dibanding pesaing

- Tujuannya untuk dapat menetapkan harga murah

- Strategi ini bisa dijalankan dengan membangun aktivitas rantai nilai yang efisien

Strategi ini akan berjalan efektif apabila:

- Konsumen sensitif terhadap harga

- Persaingan didominasi faktor harga

- Produk yang ditawarkan sama atau hampir sama penggunaannya

- Biaya perpindahan (switching cost) murah

- Pasar sangat luas

- Konsumen memiliki posisi tawar tinggi

\section{Differentiation Strategy}

- Inti strategi ini adalah memproduksi produk yang lebih unik dan memberikan nilai lebih bagi konsumen

- Strategi ini dinilai berhasil apabila keunikan produk tidak mudah ditiru oleh pesaing

- diferensiasi yang sukses akan menyebabkan perusahaan dapat menjadi pengendali harga di pasar dan memperoleh loyalitas konsumen karena keinginannya terpenuhi

Beberapa contoh produk yang menggunakan strategi diferensiasi:

- $\quad$ aneka ragam feature (Microsoft Windows, Microsoft Office, Nokia)

- pelayanan super (Federal Express)

- desain dan performa produk (BMW, Mercedes)

- prestise (BMW, Mercedes)

Strategi diferensiasi tidak hanya dapat diberlakukan pada produk tetapi di aktivitas-aktivitas rantai nilai perusahaan yang lain seperti:

- pembelian dan usaha-usaha mendapatkan bahan baku

- riset dan pengembangan produk

- pengembangan teknologi

- aktivitas-aktivitas manufaktur

- logistik keluar dan distribusi

- $\quad$ pemasaran, penjualan, dan pelayanan konsumen

Kapan strategi diferensiasi bekerja dengan baik?

- ada banyak cara membedakan produk sesuai keinginan konsumen 
- kebutuhan pembeli beraneka ragam

- banyak cara menggunakan/mengkonsumsi produk

- hanya sedikit pesaing yang mengikuti strategi yang sama

- perubahan teknologi dan inovasi produk berjalan cepat

Kelemahan dari strategi ini adalah:

- inovasi produk mendorong tingginya biaya operasi

- perusahaan harus melayani berbagai macam kebutuhan dan keinginan

Best-Cost Provider Strategy

Strategi ini bertujuan memberikan nilai lebih pada konsumen. More value for the money. Maksudnya, konsumen mau membayar lebih mahal karena menginginkan nilai lebih atau manfaat produk.

\section{Focused Strategy}

Strategi low-cost dan diferensiasi tidak hanya diterapkan untuk produksi massal atau melayani pasar besar, namun juga dapat dilakukan untuk melayani pasar kecil atau yang kita sebut dengan ceruk pasar (niche). Strategi ini disebut dengan strategi fokus, ada focused lowcost dan focused differentiation.

\section{Pengertian Strategi Diferensiasi}

Kotler (2000: 167), memberikan definisi dari diferensiasi sebagai berikut :

"Diferensiasi adalah tindakan merancang satu set perbedaan yang berarti untuk membedakan penawaran perusahaan dari penawaran pesaing”.

Sedangkan Thompson \& Strickland (1998), mendefinisikan diferensiasi sebagai berikut:

"Differentiation Strategies are an attractive competitive approach when preference are too diverse to be fully satisfied by a standardized product or when buyer requirements are too diverse to be fully satisfied by sellers with identical capabilities".

Dua pengertian diatas dapat disimpulkan bahwa esensi strategi diferensiasi adalah perusahaan dapat memberikan perbedaan yang lebih unik dari pada pesaing, sehingga dengan perbedaan itu konsumen memiliki nilai yang lebih tinggi.

\section{Sumber-sumber Diferensiasi}

Menurut Arief, Rahayu \& Thoyib (2002) terdapat beberapa sumber-sumber diferensiasi, yaitu :

1. Diferensiasi Produk. Produk fisik merupakan hal yang potensial untuk dijadikan pembeda. Perusahaan dapat membedakan produknya berdasarkan keistimewaan, 
kualitas kinerja kualitas kesesuaian, daya tahan, keandalan, mudah diperbaiki, gaya dan rancangan.

2. Diferensiasi Pelayanan. Pembeda pelayanan yang utama adalah kemudahan pemesanan, pengiriman, pemasangan, pemeliharaan dan perbaikan.

3. Diferensiasi Personel. Terdapat 6 karakteristik yang menunjukkan personil yang terlatih, yaitu kemampuan personel, kesopanan, kredibilitas, dapat diandalkan, cepat tanggap dan komunikasi.

4. Diferensiasi Saluran. Dalam melakukan diferensiasi saluran, perusahaan dapat melakukan strategi berdasarkan pada Distribusi Eksklusif, Distribusi Selektif dan Distribusi Intensif.

5. Diferensiasi Citra. Perusahaan dapat mengekspresikan citra dengan melalui lambang, media tertulis dan audio visual serta suasana.

Sedangkan menurut Tjiptono (2001: 59), strategi pemasaran yang dapat dipilih oleh perusahaan yang menerpakan strategi produk diferensiasi agar senantiasa memiliki keunggulan bersaing di pasar dapat dilakukan dengan melakukan pilihan strategi berikut ini :

1. Diferensiasi produk. Kreatifitas yang tinggi dalam menciptakan keunikan produk yang lebih menarik, sejuk, aman, nyaman, menyenangkan, karyawan yang ramah, terampil, berwawasan, dan mampu mewujudkan dalam keseharian sehingga lebih diminati oleh konsumen dibandingkan dengan produk pesaing lainnya.

2. Diferensiasi kualitas pelayanan. Kreativitas yang tinggi mengharmonisasikan unsur-unsur marketing mix : product, place, price, promotion, people, packaging, programming partnership sehingga kualitas jasa yang dirasakan oleh konsumen melebihi harapan.

3. Diferensiasi citra. Citra identik dengan atribut adalah sebuah karakteristik, yang khusus atau pembeda dari penampilan seseorang atau benda. Diferensiasi citra adalah bauran yang tepat dari elemen-elemen pencitraan, yang menciptakan citra sebuah merek.

\section{Keunggulan Bersaing}

Grant (1999: 89) mendefinisikan keunggulan bersaing sebagai berikut :

"Ketika dua perusahaan bersaing (pada pasar dan pelanggan yang sama), satu perusahaan memiliki keunggulan bersaing atas perusahaan lainnya terjadi ketika perusahaan tersebut mendapatkan tingkat keuntungan, atau memiliki potensi untuk mendapatkan laba lebih tinggi." "Competitive strategy is generally defined as an integrated set of actions taken by a firm that produce a sustainable advantage over competitors" (Varadarajan, et all, 1990: 98).

Sedangkan menurut Porter (1986: 162) keunggulan bersaing adalah kemampuan suatu perusahaan untuk meraih keuntungan ekonomis di atas laba yang mampu diraih oleh pesaing 
di pasar dalam industri yang sama. Perusahaan dikatakan memiliki keunggulan yang berkesinambungan hanya bila konsumen merasakan adanya perbedaan antara produk perusahaan dan pesaingnya, perbedaan tersebut muncul karena adanya gap kapabilitas dan gap tersebut dapat dipertahankan. Konsep nilai keunggulan bersaing dari adanya core competence yang menekankan pada koordinasi antara production skills dan teknologi (Porter, 1986: 167), yang menunjukkan posisi perusahaan di antara pesaing, baik ancaman timbulnya pesaing baru, bentuk substitusi maupun kejenuhan dari pelanggan sendiri digambarkan sebagai berikut :

\section{Forces Driving Industry Competitons}

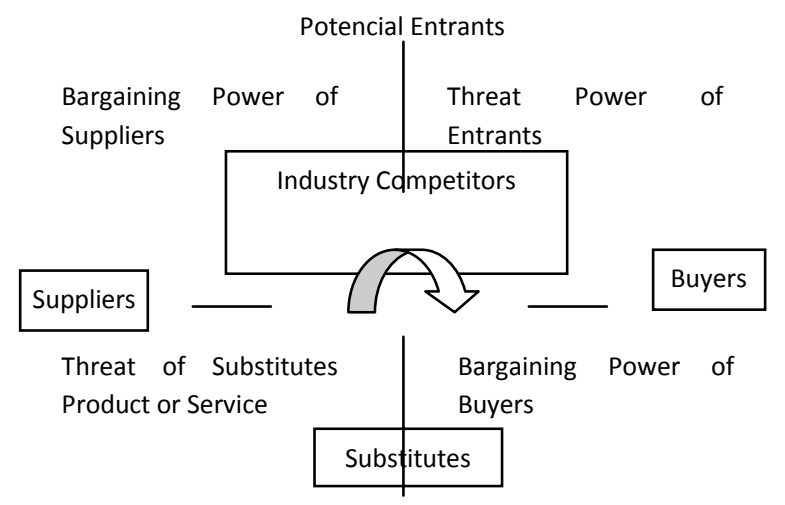

\section{Penelitian Terdahulu Yang Berhubungan dengan Tema}

Glueck \& Jauch (1996: 76), menyatakan bahwa Strategi adalah rencana yang disatukan, luas dan terintegrasi yang menghubungkan keunggulan strategi perusahaan dengan tantangan lingkungan dan yang dirancang untuk memastikan bahwa tujuan utama dari perusahaan itu dapat dicapai melalui pelaksanaan yang tepat oleh organisasi. Selanjutnya Grant (1997: 29), mengemukakan bahwa strategi dapat dirumuskan sebagai memadukan tema pokok yang memberikan koherensi serta arah tindakan dan keputusan suatu organisasi. Strategi merupakan sejumlah tindakan yang terintegrasi dan terkoordinasi yang diambil untuk mengeksploitasi kompetensi inti serta memperoleh keunggulan bersaing. Sedangkan Kompetensi Inti merupakan sumberdaya dan kemampuan yang telah ditentukan sebagai sumber keunggulan bersaing bagi perusahaan terhadap pesaingnya, (Hitt, Ireland \& Hoskisson, 1997: 193).

Setiap individu dalam organisasi harus mampu melihat visi,misi, yang kemudian ditunjang dengan penyusunan strategi maupun taktik yang tepat sehingga mampu menciptakan sustainable competitive advantage bagi perusahaan tersebut (Gunawan, 1999). 
Sedangkan Thomson \& Strickland (1998: 128), mengungkapkan bahwa para manajer korporat harus bisa menciptakan sebuah langkah strategis multibisnis dan multi industri yang beragam.

Urtasun \& Gutierez (2000) melakukan penelitian dengan judul Strategic Similarity and Performance : A Panel Data Of Urban Hotel. Penelitian ini dilakukan pada industri hotel di Madrid, Spanyol. Tujuan penelitian ini adalah untuk mengetahui perbedaan strategi yang dilakukan perusahaan dibandingkan pesaingnya. Hasil penelitian menunjukkan bahwa dimensi harga dan pelayanan mempunyai korelasi terhadap kinerja, artinya kedua dimensi tersebut mempunyai tingkat kesamaan yang tinggi. Dimensi lokasi, mempunyai korelasi negatif terhadap kinerja, artinya dimensi lokasi antara satu hotel dengan lainnya berbeda. Sedangkan dimensi ukuran tidak berhubungan dengan kinerja.

Hall dalam Arief, Rahayu \& Thoyib (2002) dengan penelitian berjudul The Strategic Analysis Of Intangible Resources. Dasar pemikirannya, faktor yang menunjang terciptanya keunggulan bersaing bagi perusahaan adalah kemampuan membedakan diri dengan pesaing. Kemampuan membedakan diri tersebut didasarkan pada sumber daya yang tidak dapat dirasakan (Intangible Resources).

Hasil penelitian Sukawati (2007) dalam penelitian yang berjudul "Pengaruh Strategi Diferensiasi Terhadap Kepuasan Pelanggan Pita Maha A Tjampuhan Resort \& Spa di Ubud" menunjukkan bahwa kepuasan konsumen dan keunggulan bersaing hotel ini dipengaruhi oleh variable diferensiasi tawaran jasa, diferensiasi layanan atau penyerahan jasa, dan diferensiasi citra. Hasil analisis dengan menggunakan taraf nyata 5\% menunjukkan bahwa ketiga variabel tersebut, baik secara keseluruhan maupun secara parsial, berpengaruh signifikan terhadap kepuasan konsumen.

Dalam industri jasa perusahaan dapat memenangkan persaingan dengan menyampaikan secara konsisten layanan yang bermutu tinggi dibandingkan dengan para pesaing dan yang lebih tinggi daripada harapan pelanggan (Kotler, 2000: 498). Perusahaan jasa menghadapi tiga tugas dalam pemasaran: (1) mendiferensiasi tawaran, penyerahan, dan citranya; (2) mengelola mutu jasa agar mencapai atau melampaui harapan pelanggan; (3) mengelola produktivitas karyawan dengan membuat karyawan bekerja lebih terampil, meningkatkan mutu jasa dengan melepas mutu tertentu, mengindustrikan jasa, menemukan solusi produk baru, merancang jasa yang lebih efektif.

Keunggulan bersaing yang berkesinambungan adalah kemampuan suatu perusahaan untuk menciptakan suatu produk yang pada saat pesaing berusaha untuk menirunya akan 
selalu mengalami kegagalan secara signifikan. Pada saat perusahaan menerapkan strategi tersebut dan perusahaan pesaing tidak secara berkesinambungan menerapkannya serta perusahaan lain tidak mampu meniru keunggulan strategi tersebut maka perusahaan lain tidak mampu meniru keunggulan strategi tersebut, maka perusahaan dikatakan memiliki keunggulan bersaing yang berkesinambungan (Hit, Ireland \& Hoskisson, 1997: 5).

Menurut Zyman (2000: 174), banyak perusahaan yang sukses dalam menjual produk karena produk mereka memiliki citra jelas yang menentukan posisi mereka di titik yang secara potensial menarik dalam pilihan konsumen. Berbagai konsep yang berkembang saat ini menyiratkan bahwa pentingnya citra sebagai sarana atau alat untuk meraih keunggulan bersaing di pasar. Begitu perusahaan telah secara jelas mendefinisikan citranya kepada pelanggan, maka langkah berikutnya adalah mengkomunikasikan citra tersebut agar elemen ini menjadi sumber keunggulan bersaing yang dimiliki dalam jangka panjang (Grede dalam Sukawati, 2007).

Penelitian yang dilakukan oleh Patibandla \& Sanyal (2001) menyebutkan bahwa salah satu keputusan strategis yang penting yang dilakukan oleh perusahaan untuk meraih keunggulan kompetitif dalam menembus pasar kompetitif adalah melalui strategi diferensiasi produk. Hasil penelitian ini juga menyebutkan bahwa perusahaan-perusahaan yang menjual produk dan kualitas yang sama akan mengalami persaingan yang sangat kompetitif, dengan perusahaan yang telah lebih dahulu berdiri di pasar jika perusahaan tersebut tidak melakukan strategi diferensiasi produk dalam menembus pasar. Menurut peneliti salah satu penyebabnya adalah perusahaan yang telah berdiri di pasar lebih dahulu memiliki sunk cost terhadap pasar yang telah tertanam dengan baik dalam bentuk hubungan yang baik dengan saluran pemasaran dan citra yang sudah terbangun dengan baik.

Penelitian yang dilakukan oleh Cierpicki, Wright \& Sharp (2002) menyebutkan bahwa faktor utama penyebab kegagalan produk dalam meraih keunggulan kompetitif adalah kurangnya diferensiasi produk. Sedangkan penelitian yang dilakukan oleh Kashyap (2001) menunjukkan bahwa pemberian pelayanan yang lebih baik terhadap konsumen berpengaruh memperkuat dan menunjang hubungan jangka panjang perusahaan dengan konsumen. Hasil penelitian ini juga menyebutkan bahwa pemberian servis yang lebih baik dapat meningkatkan kepuasan konsumen yang akan memberikan sinyal ke pasar bagi perusahaan untuk meraih keunggulan kompetitif.

Pemilihan produk diantara banyaknya tawaran yang ada di pasar selalu didasarkan pada adanya perbedaan, baik secara implisit maupun eksplisit. Literatur Psikologi merujuk 
kepada fakta bahwa perbedaan mencolok yang terkait dengan suatu produk akan merangsang daya ingat karena perbedaan tersebut akan diapresiasikan secara intelektual (Trout, 1999: 14).

Perusahaan jasa perlu melakukan diferensiasi melalui inovasi yang bersifat pre-emtive dalam jangka panjang. Pre-emtive disini maksudnya adalah implementasi suatu strategi yang baru bagi suatu bisnis tertentu. Karena merupakan yang pertama, maka dapat menghasilkan keterampilan atau asset yang dapat merintangi, mencegah, atau menghalangi para pesaing untuk melakukan duplikasi atau membuat tandingannya (Macmillan dalam Tjiptono, 2001: 145-146)

Penelitian yang dilakukan oleh Arief, Rahayu \& Thoyib (2002) menunjukkan bahwa dari hasil analisa kuantitatif dengan menggunakan alat analisa Regresi Linier Berganda, diperoleh hasil bahwa faktor-faktor harga, pelayanan, promosi dan lokasi merupakan faktor keunggulan bersaing yang digunakan oleh industri Hotel . Berdasarkan analisis Determinasi Partial diperoleh hasil bahwa faktor yang paling berpengaruh terhadap keunggulan bersaing adalah harga dengan nilai koefisien determinasi sebesar 0,922.

Remiasa (2007) dalam penelitiannya berjudul "Perencanaan Strategis Pemasaran untuk Menciptakan Sustainable Competitive Advantage (Kasus Pada Program Studi Manajemen Perhotelan UK Petra Di Surabaya)" menyebutkan bahwa dengan analisa SWOT dan IE-Matrix, disarankan beberapa hal, yaitu : strategi market intensive dilakukan melalui penetrasi pasar dan pengambangan pasar, mengembangkan strategi differensiasi yang menunjukkan ciri sekolah perhotelan yang berbeda sehingga mampu menciptakan sutainable competitive advantage.

Perusahaan-perusahaan yang paling berhasil akan mengadakan beberapa gabungan pendekatan SCA (Strategic Competitif Advantage), untuk diferensiasi ke dalam strategi yang tunggal. Berikut ini dasar untuk aneka diferensiasi perusahaan menurut Wajdi (2001: 193) :

1. Pilihan kualitas. Bentuk dasar dari sebuah diferensiasi yang biasanya tidak dicocoki untuk strategi harga rendah adalah strategi kualitas, yang akan membuat sebuah perusahaan melahirkan suatu produk atau pelayanan yang unggul dari pada pesaing. Strategi kualitas berarti bahwa barang, apakah itu hotel, mobil, atau computer akan menjadi barang yang menawarkan kenaikan kegunaan/keuntungan pelanggan.

2. Kesadaran Merk Produk (Brand Awareness). Brand awareness sering diterima apa adanya oleh perusahaan tetapi kenyataannya dapat sebagai aset strategi. Di beberapa industri dimana ada produksi yang sama, kesadaran memberikan sebuah kompetitif terus-menerus berbeda dari waktu ke waktu. Jenis-jenis kesadaran dapat menjadikan 
keunggulan kompetisi. Pertama, kesadaran sebagai sebuah ketenaran (faniliaritas) dan masyarakat menyukai ketenaran terutama pada produk rendah seperti sabun, permen karet, ketenaran mempengaruhi keputusan pembeli. Kedua, kesadaran merupakan tanda sebuah kehadiran, komitmen, dan substansi, menandai bahwa dapat menjadi penting bagi pembeli besar dan konsumen umum. Logikanya jika nama telah diketahui maka harus ada alasan yang kuat tentang nama itu. Ketiga, langkah persamaan dalam seleksi sebuah agen advertise sebuah mobil di test, atau dipertimbangkan. Jenis recall dapat menjadi sangat penting dalam group ini.

3. Orientasi pelanggan. Fokus pelanggan adalah sesuatu di mana banyak organisasi berkeinginan untuk memilikinya. Masalahnya adalah membedakan antara rayuan dan budaya dasar dengan seperangkat program yang bergabung mewakili suatu SCA yang andal. Pertama, perusahaan yang terdorong pelanggan seharusnya memiliki pemahaman yang mendalam tentang pelanggan, berdasarkan pada hubungan langsung dan penelitian pasar. Kedua, perusahaan seharusnya mempunyai pemikiran yang jelas tentang apa yang diinginkan dari pengamatan pelanggan dan apa sebenarnya mereka itu dan mengapa. Ketiga, bisnis tersebut seharusnya meyakinkan bahwa hal ini menawarkan kualitas atau nilai dengan mengukur kepuasaan pelanggan dan reaksi dari hasil masukan.

4. Ciri-ciri (khusus) produk. Diferensiasi sifat tidak terbatas hanya pada sifat-sifat produk tersebut yang diharapkan pelanggan. Perluasan produk tidak biasa diharapkan oleh pelanggan, tetapi mereka dapat menjadi dasar bagi diferensiasi sepanjang pelanggan memperhatikan dan menghargainya. Pemikiran tersebut untuk merubah sifat dari bisnis dan kaitannya dengan faktor-faktor kunci sukses untuk dapat mengembangkan SCA. Hal itu selanjutnya dapat untuk menyusun ide perluasan produk yang mana :

a. Pelanggan akan mempunyai nilai cukup untuk membayar, dan

b. Akan mewakili keunggulan persaingan yang dapat dipertahankan dan tidak mudah untuk ditiru oleh para pesaing.

5. Loyalitas barang. Aset penting yang tahan lama bagi beberapa bisnis adalah kesetiaan dari pelanggan. Para pesaing sering kali memproses ulang atas meningkatkan produk atau jasanya, tetapi mereka masih harus menghadapi pekerjaan untuk membuat pelanggan mengganti merk. Kesetiaan pelanggan akan suatu merek, bertahan dari pergantian, dapat didasarkan pada kebiasaan yang sederhana. Di antaranya : tidak adanya motivasi untuk berubah dari kebiasaan, kesukaan (adanya kegemaran yang sejati 
dari suatu merek atau simbolnya, mungkin berdasarkan pada pengalaman penggunaan yang lama), atau perputaran harga. Perputaran harga akan terjadi bagi pemakai perangkat lunak (software), contohnya saat investasi nyata (substansial) telah dibuat dalam pelatihan karyawan untuk mempelajari sistem software khusus.

6. Ciri-ciri (khusus, keistimewaan) pelanggan. Untuk pelanggan tertentu menginginkan suatu produk dengan jenis dan model tertentu yang tidak sama dengan pelanggan lainnya. Dalam strategi diferensiasi perusahaan membedakan produk yang disesuaikan dengan keinginan suatu kelompok pelanggan tertentu yang mempunyai keistimewaan dan ciri khusus.

7. Keunggulan teknik. Pendekatan kompetitif yang lain adalah mempertahankan keunggulan tehnologi, khususnya untuk perusahaan-perusahaan tehnologi tinggi. Pertanyaannya adalah apakah kehadirannya dalam keunggulan tehnologi tersebut pada awal inovasi tehnologi. Hal ini akan mempunyai keuntungan khusus pada saat tersebut, yang dapat dinilai berdasarkan dua perspektif. Pertama, beberapa industri yang konsisten pada kompetisi bertahun-tahun yang mempunyai kemampuan dalam $\mathrm{R} \& \mathrm{D}$, manufaktur dan pengenalan produk baru dapat menjadi pendorong kesuksesan. Sebagai contohnya Compac dalam computer dan intel dalam Mikroprosesor. Kedua, konsepnya yang nyata. Beberapa perusahaan mengandalkan tehnologi tingkat tinggi, produksinya selalu up to date. Sebagai contoh alat dari Hewlett-Packard yang selalu dijadikan andalan.

8. Saluran distribusi. Saluran distribusi yang dikendalikan perusahaan dapat menjadi aset kunci. Adanya akses untuk supermarket dapat menjadi keuntungan kompetitif tinggi untuk perusahaan dalam membuat kategori paket produk bagi pelanggan. Aset itu juga menjadi dasar dari keberhasilan produk baru, yang diperoleh dari adanya asosiasi untuk mendukung produk dengan promosi dan iklan, serta dana sebagai kekuatan penjualan effektif. Dari hal ini akibatnya kompetitor mendapat kesulitan dalam menempatkan posisi, apakah hanya sebagai merk keempat atau kelima.

9. Keluasan produk line. Strategi diferensiasi yang lain adalah memperluas jajaran lini produk. Jadi pelanggan disediakan sistem solusi “one stop shoping”. Keandalan one stop shoping ditunjukkan klasifikasi jajaran produk yang sangat luas dan dalam yang menggambarkan sosok manusia dari sudut pandang luas. Seleksi lini produk yang semakin luas membuat perusahaan mendominasi para kompetitornya ke dalam klasifikasi produk. Dominannya klasifikasi pengecer ditunjukkan dalam beberapa kategori seperti produk rekaman, buku, ban dan sepatu. Sebuah jajaran produk luas 
juga menjadikan perintang untuk mempelajari pendahulu pasar, dalam hubungannya kekuasaan pada jajaran produk dan hambatan yang diasosiasikan. Jika suplier terlihat memiliki dasar jajaran produk yang luas, dengan jajaran penuh, dan hanya terlihat ada tersisa ekonomi skala kecil, maka membuat sulit para kompeti-tor. Potensi perluasan produk dapat bertambah dengan dipengaruhi suatu penemuan alat.

\section{KESIMPULAN \& SARAN}

\section{Kesimpulan}

Berdasarkan hasil pembahasan diatas dapat disimpulkan sebagai berikut :

1. Strategi adalah suatu sarana bagi organisasi untuk mencapai tujuannya. Karena merupakan sarana maka strategi diharapkan dapat menjawab tantangan dan merebut peluang yang ada melalui persaingan yang semakin kempetitif dimasa yang akan datang dengan berbagai keunggulan yang dimiliki suatu organisasi.

2. Porter (1986) mengemukakan untuk menghadapi kekuatan persaingan perlu adanya strategi yang dikenal dengan strategi generik yang merupakan cara mendasar bagi perusahaan untuk mencapai profitabilitas diatas rata-rata industri dengan memiliki sustainable competitive advantage strategi tersebut terdiri dari: strategi kepemimpinan biaya (cost leadership), strategi diferensiasi (differentiation), dan strategi focus (baik focus kepemimpinan biaya ataupun focus diferensiasi).

3. Esensi strategi diferensiasi adalah perusahaan dapat memberikan perbedaan yang lebih unik dari pada pesaing, sehingga dengan perbedaan itu konsumen memiliki nilai yang lebih tinggi. Sumber-sumber diferensiasi terdiri dari : diferensiasi produk, pelayanan, personel, distribusi, dan citra.

4. Perusahaan dikatakan memiliki keunggulan yang berkesinambungan hanya bila konsumen merasakan adanya perbedaan antara produk perusahaan dan pesaingnya, perbedaan tersebut muncul karena adanya gap kapabilitas dan gap tersebut dapat dipertahankan. Konsep nilai keunggulan bersaing dari adanya core competence yang menekankan pada koordinasi antara production skills dan teknologi.

5. Strategi diferensiasi berpengaruh pada keunggulan bersaing suatu perusahaan, karena dengan adanya perbedaan suatu perusahaan yang tidak dimiliki oleh perusahaan yang lain dia akan bisa memenangkan persaingan. 


\section{Saran}

Berdasarkan hasil pembahasan diatas dapat dikemukakan beberapa saran yang diharapkan dapat bermanfaat bagi semua pihak berkaitan dengan penerapan strategi diferensiasi untuk menciptakan keunggulan bersaing.

1. Dengan memahami pentingnya strategi diferensiasi, diharapkan perusahaan dapat menciptakan perbedaan dengan pesaingnya.

2. Untuk perusahaan yang sudah menerapkan strategi diferensiasi diharapkan dapat lebih mempertegas dan mengkomunikasikan perbedaannya.

3. Pilihan diferensiasi meliputi: diferensiasi produk, diferensiasi pelayanan, dan differensiasi citra yang berpengaruh terhadap keunggulan bersaing, sehingga perusahaan dapat menerapkan Strategi Diferensiasi dengan berdasarkan pada pilihan strategi tersebut. 


\section{DAFTAR PUSTAKA}

Arief M., Rahayu M., \& Thoyib A., 2002, Analisis Strategi Diferensiasi Yang berpengaruh terhadap Keunggulan Bersaing Pada Industri Hotel melati III di Kota Malang, Jurnal Manajemen, hal 49-71

Cierpicki S., Wright M. \& Sharp B., 2002, Managers' knowledge of Marketing Principles : the Casse of New Product Development, Journal of Empirical Generalisations in Marketing Science.

Glueck W.F. \& Jauch, L.R., 1996, Manajemen Strategi dan Kebijaksanaan Perusahaan, Edisi ketiga, Penerbit Erlangga, Jakarta

Grant R.M., 1997, Analisis Strategi Kontemporer. Konsep, Teknik, Aplikasi, Penerbit Erlangga. Jakarta.

Gunawan S., 1999, Tren Pemasaran Abad 21, makalah Seminar, Disajikan pada Seminar Sehari "Marketing dan Accounting dalam Era Globalisasi”, Surabaya, 21 juli 1999

Hitt M.A., Ireland R.D. \& Hoskisson R.E., 1997. Manajemen Strategis Menyongsong Era Persaingan dan Globalisasi, Penerbit Erlangga, Jakarta.

Hunger J.D., Wheelen T. , 1995, Strategic Management And Business Policy, Fifth Edition, Addison Wesley Publishing Company, Inc.

Kashyap P., 2001, The Effects of Service Guarantees on External and Internal Markets, Academy of Marketing Science Review.

Kotler, Philip, 2000, Marketing Management, The Millennium Edition, International Edition, New York, Prentice Hill

Patibandla M. \& Sanyal A., 2001, Product Differentiation and market Demand for TNCs in an Emerging Economy : The Case of Indian Durable Costumer Good Industries, Department of International Economic, Copenhagen Business School.

Pearce \& Robinson, 1997, Strategic Management : Formulation, Implementing and Controlling, alih bahasa Agus Maulana, Bina Rupa Aksara, Jakarta.

Porter, Michael E, 1980, Competitive Strategy, First Edition, Free Press, New York.

Porter, M.E., 1986, Competitive Advantage, The Free Press, New York.

Remiasa, Marcus, 2007, Perencanaan Strategis Pemasaran untuk Menciptakan Sustainable Competitive Advantage (Kasus Pasa Program Studi Manajemen Perhotelan UK Petra Di Surabaya), Jurnal Manajemen Perhotelan, Vol. 1, No. 1, Maret 2005 : 14-23, Universitas Kristen Petra 
Sukawati, T.G.R., 2007, Pengaruh Strategi Diferensiasi Terhadap Kepuasan Pelanggan Pita Maha A Tjampuhan Resort \& Spa di ubud, Buletin Studi Ekonomi, Vol. 12:No. 1, 6985

Thompson A.A. \& Strickland, A.J, 1998, Strategic Management : Case Study And Concept, Tenth Edition, Irwin Mc.Graw Hill, International Publishing.

Tjiptono P., 2001, Strategi Pemasaran, Yogyakarta, Penerbit Andi

Trout, J., 2001, Differentiation or Die, Jakarta, Penerbit Erlangga

Urtasun A. \& Guiterez I., 2000, Strategic Similarity And Performance : A Panel Data Of Urban Hotel, Universidad Publica De Nauorra Departmento De Gestion De Empresa Campus De arrododia, Spain.

Varadarajan, et all., 1990, Contemporary perpectives on Strategic Market Planning, Allyn \& Bacon A Division of Simon \& Schuster, Inc., Boston London Sydney Toronto.

Wajdi M. F. , 2001, Manajemen Strategi, Edisi 2, Penerbit Erlangga, Jakarta

Zyman S., 2000, The End of Marketing as We Know it, Jakarta, PT. Gramedia Pustaka Utama.

\section{IDENTITAS DIRI}

Nama

Jenis Kelamin

Tempat dan Tanggal Lahir

Status Perkawinan

Agama

Alamat Rumah

Telp.

Alamat E-mail
: DWI SULISTIANI, SE, MSA, Ak, CA

: Laki-laki $\mathbf{v}$ Perempuan

: Tulungagung, 2 Oktober 1979

: $\mathbf{v}$ Kawin $\square$ Belum Kawin $\square$ Duda/Janda

: Islam

: Jl. Akordion 187 A, Malang

: 087759977254/ 03415471681

: tiaraakbar2006@yahoo.com 